\title{
Effect of Some Environmental Factors on Incidence and Severity of Angular Leaf Spot of Cotton in Yola and Mubi, Adamawa State, Nigeria
}

\author{
N. Z. Tuti' ${ }^{1}$ H. Nahunnaro' ${ }^{2}$, K. Ayuba ${ }^{3}$ \\ ${ }^{1}$ Federal Polytechnic, Mubi, Nigeria \\ ${ }^{2}$ Department of Crop Protection, Modibbo Adams University of Technology, Yola, Nigeria \\ 3 International Crops Research Institute for the Semi-Arid Tropics (ICRISAT), Tarauni, Nigeria \\ Email: hycenth.nahunnaro@yahoo.com
}

Received 15 July 2015; accepted 21 August 2015; published 25 August 2015

\begin{abstract}
Environmental factors such as relative humidity and rainfall generally have been found to increase the incidence, rate of spread and severity of diseases thereby reducing yield of crops. Study was conducted on five cotton varieties, which were artificially inoculated with bacterial blight pathogen to determine the effects of rainfall and relative humidity on incidence and severity of angular leaf spot (ALS) and yield of seed cotton in Yola and Mubi. Results showed that the severity of ALS was higher in Yola (58.65\%) at 13 WAS assumed to be due to higher relative humidity range of $76 \%-87 \%$ and low rainfall of $2-\mathbf{4 0 . 6} \mathbf{m m}$. This is assumed to have favoured disease development as against that of Mubi location which recorded lower severity $(51.11 \%)$ due to lower relative humidity $(42 \%$ $55 \%$ ) and rainfall (37 - $73 \mathrm{~mm}$ ). Results further revealed that at 13 WAS, SAMCOT-8 had low incidence (66\%) and severity (39\%) in Yola. This was against the much higher corresponding incidence and severity of $82 \%$ and $42 \%$ respectively that was observed in Mubi during the same period. SAMCOT-10 and SAMCOT-9 varieties were found to be highly susceptible to the disease at the same period. SAMCOT-8 recorded the highest yield of $390.00 \mathrm{~kg} \cdot \mathrm{ha}^{-1}$ in Yola and $868.09 \mathrm{~kg} \cdot \mathrm{ha}^{-1}$ in Mubi while the lowest yields of $227.17 \mathrm{~kg} \cdot \mathrm{ha}^{-1}$ was observed on SAMCOT-10 in Yola while $461.61 \mathrm{~kg} \cdot \mathrm{ha}^{-1}$ was obtained on SAMCOT-9 in Mubi. The variation in yield among these varieties might be due to the differences in their reactions to the disease. There is a need to conduct further trials in these locations to confirm the level of resistance or other aspects of these varieties to the disease.
\end{abstract}

\section{Keywords}

Angular Leaf Spot, Cotton, Rainfall, Relative Humidity, Disease Incidence and Disease Severity

\section{Introduction}

Cotton (Gossypium spp.) is a valuable agricultural commodity which plays an important role in the economy of

"Corresponding author.

How to cite this paper: Tuti, N.Z., Nahunnaro, H. and Ayuba, K. (2015) Effect of Some Environmental Factors on Incidence and Severity of Angular Leaf Spot of Cotton in Yola and Mubi, Adamawa State, Nigeria. World Journal of Engineering and Technology, 3, 19-25. http://dx.doi.org/10.4236/wjet.2015.33B004 
many developing countries by serving as a major foreign exchange earner and in domestic production of textile materials, oil, cake and edible oil [1]. It is cultivated in over 100 countries a total production of about 199 million bales of lint. China accounted for $27 \%$ of the world production figure followed by India and USA with 23\% and $15 \%$ respectively [2]. In Nigeria, cotton is adopted to most ecological zones producing 1.48 million bales in 2010 [3]. However, the production potential of this valuable cash crop has been constrained by the prevalence of a number of fungal, bacterial and nematodes diseases which affect yield and fibre quality [4] [5]. The incidences and severities of these diseases are restricted by ecological and climatic differences in the crop environment [5][7]. Among the diseases which affect cotton, bacterial blight incited by Xanthomonas axonopodis pv. malvacearum is the most devastating disease in all cotton growing regions of the world and Nigeria in particular with an estimated yield loss of $10 \%-20 \%$ in affected plants [8]. Yield losses of up to $10 \%-50 \%$ have been recorded in other cotton growing regions [9] and such loses on annual basis are dependent on severity of epidemic, cotton species susceptibility and environmental factors [10] [11].

According to [9], high rainfall, relative humidity as well as warm temperature favour disease development which in turn affect yield. Free water is required for foliar infection and secondary spread is favoured by high humidity following periods of wind and rain which distribute the bacteria within the crop canopy. Provided the relative humidity is $85 \%$, the optimum temperature for disease development is around $36^{\circ} \mathrm{C}$ [12] [13]. Presently, there is a growing advocacy by the Nigerian government to boost agricultural productivity to achieve food and raw materials sufficiency in line with the vision 2020. Cotton is one of the major cash crops earmarked for increased production in all the cotton producing zones of the country with the aim of achieving the goals of the government for a sustainable cotton production to revamp our ailing textile industries and also for export.

This study is therefore conducted to ascertain the reaction of some cotton varieties to Xanthomonas axonopodis pv. malvacearum and the influence of environmental factors on incidence and severity of angular leaf spot.

\section{Materials and Methods}

This study was conducted in Yola and Mubi all in northeastern Nigeria during the 2011 cropping season. One of the field trials was conducted at the Teaching and Research Farm of the Department of Crop Protection, Modibbo Adama University of Technology, Yola. Yola is located between latitude $9^{\circ} 11^{\prime} \mathrm{N}$ and $9^{\circ} 19^{\prime} \mathrm{N}$ and longitude $13^{\circ} 1^{\prime} \mathrm{E}$ and $12^{\circ} 31^{\prime} \mathrm{E}$ [14]. The second field trial was conducted at the Teaching and Research Farm of Agricultural Technology Department, Federal Polytechnic Mubi. Mubi is located between latitude $10^{\circ} 11^{\prime} \mathrm{N}$ and $9^{\circ} 26^{\prime} \mathrm{N}$ and longitude $13^{\circ} 11^{\prime} \mathrm{E}$ and $13^{\circ} 44^{\prime} \mathrm{E}$ [14].

The design used for conducting the experiments was Randomized Complete Block Design replicated three (3) times. The experimental fields measured $29 \mathrm{~m} \times 11 \mathrm{~m}$ with plots measuring $5 \mathrm{~m} \times 3 \mathrm{~m}$, and alleys of $1 \mathrm{~m}$ pathway between plots and replicates. The five cotton varieties (SAMCOT-8, SAMCOT-9, SAMCOT-10, SAMCOT11 and SAMCOT-12) were obtained from the Institute of Agricultural Research (IAR), Samaru, Zaria.

The cotton seeds, before sowing were inoculated with infected crushed cotton plant leaves which served as initial inoculum and sown at a spacing of $90 \mathrm{~cm} \times 45 \mathrm{~cm}$ with five plants per stand which was later thinned to two plants per stand at 3 weeks after sowing (WAS) (Idem, 1999). Diuron was applied immediately after sowing at the rate of $1 \mathrm{~kg}$ (150 $\mathrm{ml}$ in 20 litre sprayer) per hectare as a pre-emergence herbicide, while regular hand weeding was done to control weeds which emerge later [15]. Cypermethrin (Cymbush) and Imidacloprid (Courage $^{\circledR}$ ) application was carried out at the ratio of $20 \mathrm{ml}$ : $40 \mathrm{ml}$ of Smash and Courage respectively per 20 litre knapsack sprayer to control insect pests associated with cotton. Fertilizer containing nitrogen was applied at the rate of $60 \mathrm{~kg} \cdot \mathrm{ha}^{-1}$, phosphorus in the form of $\mathrm{P}_{2} \mathrm{O}_{5}$ at the rate of $30 \mathrm{~kg} \cdot \mathrm{ha}^{-1}$, and potassium in the form of $\mathrm{K}_{2} \mathrm{O}$ at the rate of $30 \mathrm{~kg} \cdot \mathrm{ha}^{-1}$.

Isolated bacterial pathogens $\left(10^{8} \mathrm{cfu} / \mathrm{ml}\right)$ were suspended in distilled water and later sprayed under the leaf surfaces of the plants in the evening using a pressurized hand sprayer to increase the chances of infection by the pathogen.

Data were collected on incidences and severity of angular leaf spot from 7 - 13 WAS and yield $\left(\mathrm{kg} \cdot \mathrm{ha}^{-1}\right)$. Weather data were also collected from meteorological stations of two higher institutions in the study locations namely Modibbo Adama University of Technology, Yola and Adamawa State University, Mubi. Disease incidence was calculated using the formula;

$$
\text { Disease Incidence }=\frac{\text { Number of infected plants }}{\text { Total number of plants assesed }} \times 100
$$


While disease severity was calculated using a scale of 0 - 6 according to the method of [16] and the formula used was:

$$
\text { Disease Severity }=\frac{\text { Sum of individual ratings }}{\text { Total number of plants assesed } \mathrm{x} \text { highest score in the ratings }} \times 100
$$

The data collected were analyzed using the Generalized Linear Model (GLM) procedure of Statistical Analysis System (SAS) appropriate for RCBD and means were separated using Duncan Multiple Range Test (DMRT).

\section{Results}

The results on the influence of relative humidity and rainfall on incidence of ALS revealed a gradual increase in the percentage incidence of the disease at 7 - 13 WAS at Yola (Table 1) and significant difference $(\mathrm{P} \leq 0.05)$ among the varieties. At 7 WAS SAMCOT-8 recorded the lowest incidence of $14.00 \%$ while SAMCOT-9 had a higher value of $18.00 \%$. At $13 \mathrm{WAS}$, results revealed higher significant $(\mathrm{P} \leq 0.01)$ difference between varieties, with SAMCOT-8 still recording the lowest incidence of $66.66 \%$ while SAMCOT-10 recorded the highest incidence of $88.00 \%$.

In Mubi location, results also revealed a gradual increase in the percentage incidence of the disease from 7 to 13 WAS (Table 2). It further showed that there was a significant difference $(P \leq 0.05)$ between the varieties at 7 - 11 WAS with SAMCOT-8 and 12 recording the lowest percentage incidence of $18.66 \%$ at 7 WAS while SAMCOT-9 had a percentage incidence of $24.66 \%$. At 11 WAS, there was no statistical difference between the mean incidences. SAMCOT-8 had the lowest disease incidence and the rest of varieties statistically similar.

Similar trend were observed with regards to severity of angular leaf spot in Yola (Table 3). There was a highly significant $(\mathrm{P} \leq 0.01)$ difference between varieties at 7 WAS and 13 WAS with SAMCOT-8 recording the lowest severity of $12.67 \%$ and $39 \%$ respectively. The highest severity at 7 WAS and 13 WAS was observed on SAMCOT-9 (16.98) and SAMCOT-10 (58.60\%) respectively. In Mubi, result revealed highly significant $(\mathrm{P} \leq 0.01)$ variation from 8 - 13 WAS (Table 4$)$ the lowest severity of $15 \%-80 \%$ was observed on SAMCOT10 while SAMCOT- 12 had the highest severity of $25 \%-35 \%$ at 8 WAS. At 13 WAS, SAMCOT-8 recorded the lowest severity of $40.32 \%$, while the rest are statistically similar.

The results on influence of rainfall and relative humidity on incidence and severity of angular leaf spot 7 - 13 WAS, revealed a gradual increase in the percentage incidence and severity of the disease with increase in relative humidity and amount of rainfall in both locations (Table 5).

Results for yield of seed cotton (Table 6) indicated highly significant $(\mathrm{P} \leq 0.01)$ differences in both locations between the varieties. In Yola, it was observed that SAMCOT-8 had the highest mean value of $390.00 \mathrm{~kg} \cdot \mathrm{ha}^{-1}$, while lower value of $227.17 \mathrm{~kg} \cdot \mathrm{ha}^{-1}$ was observed on SAMCOT-10. In Mubi location, similar trend was observed with SAMCOT-8 recording a much higher yield value of $868.09 \mathrm{~kg} \cdot \mathrm{ha}^{-1}$, while SAMCOT-9 had the lowest weight of $461.61 \mathrm{~kg} \cdot \mathrm{ha}^{-1}$.

\section{Discussion}

Disease severity is an important factor in determining the performance and yield of crops as high disease severity

Table 1. Mean effect of relative humidity and rainfall on incidence of Angular leaf spot at 7 - 13 WAS at Yola.

\begin{tabular}{|c|c|c|c|c|c|c|c|}
\hline \multirow{2}{*}{ Variety } & \multicolumn{7}{|c|}{ Weeks after sowing (WAS) } \\
\hline & 7 & 8 & 9 & 10 & 11 & 12 & 13 \\
\hline SAMCOT-8 & $14.00 \mathrm{~b}$ & 21.33d & $30.00 \mathrm{~b}$ & $36.66 c$ & 43.33d & 50.66d & $66.66 \mathrm{c}$ \\
\hline SAMCOT-9 & $18.00 \mathrm{a}$ & $29.33 a$ & $36.66 a$ & $44.00 \mathrm{~b}$ & 57.33ab & $74.00 \mathrm{~b}$ & $84.66 a$ \\
\hline SAMCOT-10 & 17.33ab & $25.33 \mathrm{bc}$ & 39.33a & 49.33a & $60.66 \mathrm{a}$ & $79.33 a$ & $88.00 \mathrm{a}$ \\
\hline SAMCOT-11 & 16.66ab & 26.66ab & $36.00 \mathrm{a}$ & $46.00 \mathrm{~b}$ & $56.66 b$ & $70.00 \mathrm{~b}$ & 83.33a \\
\hline SAMCOT-12 & 15.33ab & 23.33cd & $32.00 \mathrm{~b}$ & 39.33c & $48.66 \mathrm{c}$ & $58.66 \mathrm{c}$ & $76.66 \mathrm{~b}$ \\
\hline Probability of F & 0.1716 & 0.0002 & 0.0002 & $<0.0001$ & $<0.0001$ & $<0.0001$ & $<0.0001$ \\
\hline
\end{tabular}

Column means with the same letter(s) are not significantly different according to DMRT. 
Table 2. Mean effect of relative humidity and rainfall on incidence of Angular leaf spot at 7 - 13 WAS at Mubi.

\begin{tabular}{ccccccccc}
\hline \multirow{2}{*}{ Variety } & \multicolumn{7}{c}{ Weeks after sowing (WAS) } \\
\cline { 2 - 8 } & 7 & 8 & 9 & 10 & 11 & 12 & 13 \\
\hline SAMCOT-8 & $18.66^{\mathrm{c}}$ & $25.33^{\mathrm{b}}$ & $30.66^{\mathrm{b}}$ & $36.66^{\mathrm{b}}$ & $63.33^{\mathrm{bc}}$ & $72.00^{\mathrm{c}}$ & $82.66^{\mathrm{c}}$ \\
SAMCOT-9 & $24.66^{\mathrm{a}}$ & $29.33^{\mathrm{a}}$ & $36.00^{\mathrm{a}}$ & $44.00^{\mathrm{a}}$ & $68.66^{\mathrm{a}}$ & $80.00^{\mathrm{c}}$ & $86.00^{\mathrm{c}}$ \\
SAMCOT-10 & $21.33^{\mathrm{b}}$ & $29.33^{\mathrm{a}}$ & $37.33^{\mathrm{a}}$ & $45.33^{\mathrm{a}}$ & $68.00^{\mathrm{a}}$ & $81.33^{\mathrm{c}}$ & $86.00^{\mathrm{c}}$ \\
SAMCOT-11 & $22.00^{\mathrm{b}}$ & $27.33^{\mathrm{ab}}$ & $36.00^{\mathrm{a}}$ & $42.66^{\mathrm{a}}$ & $63.33^{\mathrm{ab}}$ & $79.33^{\mathrm{c}}$ & $84.00^{\mathrm{c}}$ \\
SAMCOT-12 & $18.66^{\mathrm{c}}$ & $28.00^{\mathrm{ab}}$ & $36.00^{\mathrm{a}}$ & $44.00^{\mathrm{a}}$ & $59.33^{\mathrm{bc}}$ & $74.66^{\mathrm{c}}$ & $82.66^{\mathrm{c}}$ \\
Probability of F & 0.0001 & 0.1733 & 0.0153 & 0.0009 & 0.0058 & 0.0015 & 0.6314 \\
\hline
\end{tabular}

Column means with the same letter(s) are not significantly different according to DMRT.

Table 3. Mean effect of relative humidity and rainfall on severity of Angular leaf spot at 7 - 13 WAS at Yola.

\begin{tabular}{|c|c|c|c|c|c|c|c|}
\hline \multirow{2}{*}{ Variety } & \multicolumn{7}{|c|}{ Weeks after sowing (WAS) } \\
\hline & 7 & 8 & 9 & 10 & 11 & 12 & 13 \\
\hline SAMCOT-8 & $12.67^{\mathrm{b}}$ & $17.64^{\mathrm{d}}$ & $21.65^{\mathrm{d}}$ & $28.23^{\mathrm{b}}$ & $31.14^{c}$ & $35 . .347^{c}$ & $39.08^{d}$ \\
\hline SAMCOT-9 & $16.98^{\mathrm{a}}$ & $23.92^{\mathrm{a}}$ & $32.32^{\mathrm{a}}$ & $37.94^{\mathrm{a}}$ & $44.34^{\mathrm{a}}$ & $50.72^{\mathrm{b}}$ & $55.28^{\mathrm{b}}$ \\
\hline SAMCOT-10 & $16.94^{\mathrm{a}}$ & $24.16^{\mathrm{ab}}$ & $30.38^{\mathrm{ab}}$ & $39.19^{\mathrm{a}}$ & $46.27^{\mathrm{a}}$ & $52.74^{\mathrm{a}}$ & $58.15^{\mathrm{a}}$ \\
\hline SAMCOT-11 & $15.68^{b}$ & $20.87^{\mathrm{bc}}$ & $29.72^{\mathrm{bc}}$ & $36.88^{\mathrm{a}}$ & $44.16^{\mathrm{a}}$ & $49.88^{\mathrm{b}}$ & $56.26^{\mathrm{b}}$ \\
\hline SAMCOT-12 & $15.22^{\mathrm{b}}$ & $20.72^{\mathrm{cd}}$ & $27.97^{\mathrm{cd}}$ & $33.64^{\mathrm{b}}$ & $35.40^{\mathrm{b}}$ & $38.80^{c}$ & $40.45^{\mathrm{c}}$ \\
\hline Probability of F & $<0.0001$ & 0.0028 & $<0.0001$ & $<0.0001$ & $<0.0001$ & $<0.0001$ & $<0.0001$ \\
\hline
\end{tabular}

Column means with the same letter(s) are not significantly different according to DMRT.

Table 4. Mean effect of relative humidity and rainfall on severity of Angular leaf spot at 7 - 13 WAS at Mubi.

\begin{tabular}{cccccccc}
\hline \multirow{2}{*}{ Variety } & \multicolumn{7}{c}{ Weeks after sowing (WAS) } \\
\cline { 2 - 8 } & 7 & 8 & 9 & 10 & 11 & 12 & 13 \\
\hline SAMCOT-8 & $13.36^{\mathrm{a}}$ & $15.80^{\mathrm{cd}}$ & $18.72^{\mathrm{b}}$ & $24.57^{\mathrm{d}}$ & $32.52^{\mathrm{c}}$ & $36.61^{\mathrm{c}}$ & $40.32^{\mathrm{c}}$ \\
SAMCOT-9 & $14.10^{\mathrm{a}}$ & $25.30^{\mathrm{a}}$ & $29.79^{\mathrm{a}}$ & $40.24^{\mathrm{a}}$ & $46.14^{\mathrm{a}}$ & $50.54^{\mathrm{a}}$ & $53.62^{\mathrm{a}}$ \\
SAMCOT-10 & $12.72^{\mathrm{a}}$ & $23.64^{\mathrm{ab}}$ & $28.73^{\mathrm{a}}$ & $36.08^{\mathrm{b}}$ & $42.84^{\mathrm{b}}$ & $49.3^{\mathrm{a}}$ & $52.80^{\mathrm{a}}$ \\
SAMCOT-11 & $13.25^{\mathrm{a}}$ & $22.91^{\mathrm{bc}}$ & $28.73^{\mathrm{a}}$ & $36.26^{\mathrm{b}}$ & $44.82^{\mathrm{ab}}$ & $49.31^{\mathrm{a}}$ & $51.98^{\mathrm{ab}}$ \\
SAMCOT-12 & $14.20^{\mathrm{a}}$ & $20.52^{\mathrm{d}}$ & $24.56^{\mathrm{b}}$ & $30.16^{\mathrm{c}}$ & $32.14^{\mathrm{c}}$ & $38.13 \mathrm{~b}^{\mathrm{a}}$ & $40 . .45^{\mathrm{b}}$ \\
Probability of F & 0.3415 & $<0.0001$ & $<0.0001$ & $<0.0001$ & $<0.0001$ & $<0.0001$ & $<0.0001$ \\
\hline
\end{tabular}

Column means with the same letter(s) are not significantly different according to DMRT.

Table 5. The relative humidity and rainfall data of Yola and Mubi during the 2011 cropping season.

\begin{tabular}{ccccc}
\hline \multirow{2}{*}{ WAS } & \multicolumn{3}{c}{ Yola } & \multicolumn{2}{c}{ Mubi } \\
\cline { 2 - 5 } & R/H (\%) & Rainfall $(\mathrm{mm})$ & R/H (\%) & Rainfall (mm) \\
\hline 7 & 87 & 4.4 & 47 & 73.5 \\
8 & 76 & 14.3 & 55 & 67 \\
9 & 82 & 40.5 & 42 & 42 \\
10 & 86 & 10.4 & 44 & 37 \\
11 & 86 & 23 & 46 & 46 \\
12 & 77 & 2 & 48 & 48 \\
13 & 83 & 19 & 45 & 59 \\
\hline
\end{tabular}

Source: Department of Geography Meteorological Station, ModibboAdama University of Technology, Yolaand Department of Meteorological Services, Adamawa State University, Mubi (2011). 
Table 6. Mean effects of varieties and plant extracts on yield $\left(\mathrm{kg} \cdot \mathrm{ha}^{-1}\right)$ of seed cotton inYola and Mubi.

\begin{tabular}{|c|c|c|}
\hline \multirow{2}{*}{ Variety } & \multicolumn{2}{|c|}{ Yield $\left(\mathrm{kg} \cdot \mathrm{ha}^{-1}\right)$} \\
\hline & Yola & Mubi \\
\hline SAMCOT-8 & $390.00^{\mathrm{a}}$ & $868.9^{\mathrm{a}}$ \\
\hline SAMCOT-9 & $291.00^{c}$ & $461.61^{\text {bc }}$ \\
\hline SAMCOT-10 & $227.17^{\mathrm{d}}$ & $470.08^{d}$ \\
\hline SAMCOT-11 & $255.55^{d}$ & $523.44^{\mathrm{d}}$ \\
\hline SAMCOT-12 & $341.66^{\mathrm{b}}$ & $559.11^{b}$ \\
\hline Probability of F & $<0.0001$ & $<0.0001$ \\
\hline
\end{tabular}

Column means with the same letter(s) are not significantly different according to DMRT.

favoured by influence of relative humidity and rainfall has been found to affect photosynthesis which in turn ensures reduction of assimilates for the plant [17]. In this study, results obtained revealed a significant variation in varietal resistance and susceptibility of cotton to Xanthomonas axonopodis pv. malvacearum at 7 - 13 WAS. SAMCOT-8 and SAMCOT-12 varieties were consistently observed to record the lowest incidence, severity and high yield of seed cotton in both locations, while high disease susceptibility were observed on SAMCOT-10 in Yola and SAMCOT-9 in Mubi at the same period.

The difference in percentage incidence and severity of ALS amongst cotton varieties may be attributed to their levels of resistance to the pathogen in association with environmental factors prevailing during period of plant growth since all varieties were exposed to the same quantity of inoculum. The higher percentage susceptibility observed on SAMCOT-9, SAMCOT-10 and SAMCOT-11 may be attributed to low levels of resistance inherent in the plants. This agrees with the report by [16] who assessed the susceptibility of SAMCOT-11 and SAMCOT-13 and recorded high incidence and severity of ALS which may be related to their inherent genetic makeup to be susceptible to the disease [18] [19], and influence of rainfall and relative humidity as these varieties especially SAMCOT-8 is bred to adapt to the environments of eastern cotton growing zone of Nigeria [5]. [16] had earlier reported on the continual loss of resistance to bacterial blight by Nigerian cotton varieties including SAMCOT-8, however, results obtained from this study had proved the contrary as this variety was found to perform better.

The increase in incidence and severity of this disease followed the pattern of the percentage relative humidity and rainfall in the respective locations. In Yola, for instance, there was a high relative humidity ranging from $76 \%-87 \%$ with an irregular rainfall distribution, however, the combination of these weather elements most likely has influenced high incidence and severity of the disease. This finding agrees with [20] who reported on positive correlation between environmental conditions and disease severity in India. They further reported that maximum disease severity was observed at temperature of $26^{\circ} \mathrm{C}-27^{\circ} \mathrm{C}, 100-147 \mathrm{~mm}$ rainfall and $67 \%-77 \%$ relative humidity. [21] also reported that environmental conditions of relative humidity, rainfall and temperature had influenced the incidence and severity of Cercospora leaf spot on some cowpea varieties in Yola.

In contrast, Mubi location was characterized by low but uniform relative humidity (42\% - 55\%) and rainfall (34 - $74 \mathrm{~mm}$ ). The combination of these factors might have proved unfavourable for severe foliar infection but favoured good and vigorous plant growth and subsequently high yield. These observations agree with [22] who reported that vigorous growing leaves rarely became infected by a pathogen. Yields of seed cotton was higher in Mubi due to favourable weather conditions which ensured good crop growth and restricted the spread of the disease as compared to those obtained in Yola location. [9] reported that yield loses of up to $10 \%-50 \%$ have been reported in some cotton growing regions of the world due to severe infection by the Bacterial blight pathogen.

[23] had earlier reported on the significant increase in severity of this disease with time as influenced by rainfall and relative humidity in Kem, also in Adamawa State. [24] further reported that the principal factors influencing Xanthomonas axonopodis pv. malvacearum incidence and severity in cotton were rainfall, relative humidity, temperature, solar radiation, quantity of the inoculum and the resistant gene in the genotypes. They further reported that disease incidence increased by 3.4\% for each degree rise in average mean temperature, $12 \%$ increase when inoculum was increased from $10^{6}$ to $10^{7} \mathrm{cfu} / \mathrm{ml}, 1 \%$ increase in relative humidity and $3.7 \%$ in- 
crease in temperature for each degree increase. Results recorded in both locations appear to show a sort of relationship among disease severity, yields and weather elements.

Results from these studies have revealed a relationship between the incidence and severity of ALS and weather elements in the two locations. Rainfall and relative humidity favoured the expression of the pathogen which was variable on the different varieties. In conclusion, yields obtained from Mubi were higher than those recorded in Yola where the high relative humidity and rainfall favoured high severity and low yields amongst the varieties. Varieties such as SAMCOT-8 and SAMCOT-12 were found to be resistant to the disease and recorded higher yields in both locations. Therefore, more trials need to be conducted on these and other cotton varieties to ascertain their level of resistance to Xanthomonas axonopodis pv. malvacearum in these two and other locations.

\section{References}

[1] Anonymous (1981) Balancing Influence of N, P and K in Growth and Yield of Cotton Plant. Bangladesh Journal of Agricultural Research, 6, 36-39.

[2] USDA (2014) Cotton Production Year Book United State Department of Agriculture.

[3] USDA (2010) Cotton Production Year Book United State Department of Agriculture.

[4] Husain, T. and Tahir, M. (1993) Chemical Control of Bacterial Blight of Cotton. Pakistan Journal of Phytopathology, 5, 119-121.

[5] Idem, N.U.A. (1999) Cotton Production in Nigeria. Baraka Press and Publisher Ltd., Kaduna, 40-46.

[6] Gwary, D.M. and Nahunnaro, H. (2007) Combined Effects of Pest-Disease Complex as Influenced by Rainfall, Relative Humidity and Temperature on the Cotton Production in the Northern Guinea Savanna of Northeastern Nigeria. Journal of Arid Agriculture, 17, 27-35.

[7] Poswal, M.A.T. and Erinle, I.D. (1983) A Survey of Extent of Infection and Contamination of Cotton Seed Market and Commercial Gin Samples by Xanthomonas malvacearum (E.F. Smith) Dawson in Northern States of Nigeria. Crop Protection, 2, 473-481. http://dx.doi.org/10.1016/0261-2194(83)90068-6

[8] Erinle, I.D. (1981) A Short Guide to Bacterial Disease of Nigerian Plants, 40.

[9] Thaxton, P.M. and El-Zik, K.M. (2001) Bacterial Blight. In: Kirk Patrick, T.L. and Rothrock, C.S., Eds., Compendium of Cotton Diseases, 2nd Edition, American Phytopathological Society, 34-35.

[10] Darlington, M. (2001) Improving Host Plant Resistance without Sacrificing Yield and Quality in Zimbabwe Cotton. Zimbabwe Cotton Research Report, The Cotton Research Institute (CRI), Ministry of Agriculture.

[11] Nahunnaro, H., Gwary, D.M. and Okunsanya, B.O. (2007) An Assessment of the Reaction of Ten Cotton Genotypes to Anguler Leaf Spot Disease under Field and Controlled Conditions in Northern Guinea Savanna of Northeast Nigeria. Journal of Arid Agriculture, 1, 37-44.

[12] Hillocks, R.J. (1992) Bacterial Blight. In: Hillocks, R.J., Ed., Cotton Diseases, CAB International, Willingford, 38-85.

[13] Steve, K. (2004) Bacterial Blight (Angular Leaf Spot) of Cotton. Plant Pathology Extension, North Carolina State University. Cotton Disease Information Note, No. 3.

[14] Adebayo, A.A. (1999) Climate I: Sunshine, Temperature, Evaporation and Relative Humidity. In: Adebayo, A.A. and Tukur, A.H., Eds., Adamawa State in Maps, Paraclete Publishers and Department of Geography, Federal University of Technology, Yola, 3-5.

[15] CDC (2007) Cotton Production in Nigeria. A Publication of the Federal Ministry of Agriculture, Cotton Development Committee, Nigeria, 5-6.

[16] Poswal, M.A.T. (1989) Variation in Pathogenesity among Nigerian isolates Of Xanthomonas compestris pv. malvacearum (Smith) Dye. Proceeding of the 7th International Conference of Plant Pathogenic Bacteria, Hungary.

[17] Khan, M.A., Abdul, R. and Chohan, R.A. (2000) Biological Control of Bacterial Blight of Cotton Using Some Plant Extracts. Pakistan Journal of Agricultural Sciences, 37, 3-4.

[18] Allerd, R.W. (1991) Principles of Plant Breeding. 2nd Edition, John Wiley and Sons, New York.

[19] Sinsiri, N., Laohasiriwong, S., Jogloy, S., Toomsan, B. and Saksirirut, W. (2006) A Varietal Screening of Cowpea Cultivars (Vigna unguiculata) for a high Resistance to Pheudocercospora cruenta (Sacc.) Deighton in Northern Thailand. Pakistan Journal of Biological Sciences, 9, 641-648. http://dx.doi.org/10.3923/pjbs.2006.641.648

[20] Mohammed, A.K., Hakim, A.K., Bashir, M.T. and Abdul, R. (1999) Correlation of Environmental Conditions with Bacterial Blight Disease on Six Commercially Grown Cotton Cultivars in Five Districts of the Punjab. Pakistan Journal of Agricultural Science, 36, 1-2. 
[21] Nahunnaro, H., Ayuba, K. and Tuti, N.Z. (2012) Effects of Environment on the Incidence and Severity of Cercospora Leaf Spot (Cercosporacanescens) of Cowpea in Yola and Mubi, North-Eastern Nigeria. International Journal of Science and Development Studies, 7, 125-235.

[22] Charles, R.S. (2005) Cercospora canescens. University of Florida, USA. Record Originally Distributed by FAO, 1-4.

[23] Gwary, D.M., Nahunnaro, H. and Okusanya, B.O. (2009) Assessment of Resurgence of Bacterial Blight and Its Effects on Cotton Yield in Northern Nigeria. Achieves of Phytopathology and Plant Protection, 42, 1001-1009. http://dx.doi.org/10.1080/03235400701544010

[24] Wheeler, T.A., Shagaram, U.S., Schuster, G.L. and Gannaway, J. R. (2007) Identification of Factors that Influence Screening for Bacterial Resistance. The Journal of Cotton Science, 11, 91-97. 